\title{
PERKEMBANGAN HUKUM KEWARISAN ISLAM DI INDONESIA (Studi Perbandingan Hukum Kewarisan Dalam Kompilasi Hukum Islam Dengan Hukum Kewarisan Dalam Fiqih Konvensional )
}

\author{
Ahmad saifudin ${ }^{*}$, Akhmad Khisni $^{* *}$ \\ * Mahasiswa Program Magister (S2) Kenotariatan Fakultas Hukum UNISSULA, Semarang, e-mail: \\ ahmadsaifudinsh@yahoo.co.id \\ ${ }^{* *}$ Dosen Fakultas Hukum UNISSULA, Semarang
}

\section{ABSTRACT}

The study entitled "The Development of Islamic Inheritance Law in Indonesia (Comparative Study of Inheritance Law in Compilation of Islamic Laws With Legal Inheritance In Conventional Fiqh)" This study uses a normative juridical approach, in collecting data more emphasis on primary source material, in the form of legislation, Reviewing the rules of law as well as the theory of jurisprudence in addition to interviews to the parties related to the issues in the perusal. Based on these methods the research produces in essence: The forms of legal development of inheritance in the KHI incorporate many elements of customary law and the interests that Indonesians need today. So many forms of inheritance law have not been contained in the figh of the conventional (fiqh al-mawarits), but it has been contained and codified in the law of KHI inheritance, among others: article 171 on Joint Treasure, article 177 on the division of father asabah. Article 209 stating that foster and adopted sons receive inheritance, and if they do not receive a will, then they are entitled to a will. And KHI also acknowledged the gono-gini institute whereas the classical fiqh does not admit it (not make sub discussion). In addition, there are contradictions of the inheritance law policies contained in the KHI between the one article and the other articles, among others: article 176 on the distribution of boys and girls. This is contrary to article 229 (which is the closing provision), which states that in settling cases, the judge shall observe the values of the living law in society so that his judgment is in accordance with the sense of justice. In this case, the Indonesian Court, often inheritance distribution is not based on the principle of 2 to 1 for boys and girls. Also, article 183 on peace in the distribution of inheritance which may be contradictory to article 176 . Likewise, article 185 on the successor heirs and article 189 on the wholeness and unity of agricultural land of less than 2 (two) hectares, contrary to the principle of ijbari in Islamic inheritance law (fiqh conventional).

Keywords: Law of Inheritance, KHI, Conventional Fiqh.

\section{LATAR BELAKANG MASALAH}

Pelaksanaan hukum Islam di Indonesia, secara ringkas, mengalami pase yang cukup panjang semenjak zaman kolonial Belanda hingga zaman perubahan ini. Sejarah membuktikan bahwa aplikasi hukum Islam dalam tatanan keindonesiaan, baru teraplikasikan dalam UU No. 1 tahun 1974 tentang perkawinan, dan dalam UU No. 7 tahun 1989 tentang peradilan, itu pun dengan perjuangan yang "melelahkan" khususnya bagi umat Islam. ${ }^{1}$

Adapun sumber hukum yang dijadikan pedoman bagi para penegak hukum (Hakim), Praktisi, dan sebagainya selain undang-undang tertulis tersebut di atas adalah fatwa-fatwa ulama, baik yang tertulis dalam kitab-kitab fiqh klasik ataupun kitab-kitab fiqh modern. Sumber-sumber

1 Abdul Gani Abdullah, 1992, Pengantar Kompilasi Hukum Islam dalam Tata Hukum Indonesia, Gema Insani Press, Jakarta, hlm. 35. 
tersebut sampai hari ini merupakan bahan pelengkap dalam proses pengalian Hukum Islam.

Dengan demikian, hukum mengalami pertumbuhan dan perkembangan tanpa dapat dihindari, karena secara internal hukum menuntut dirinya untuk diinterpretasi walau dengan varianvarian dan tingkat yang berbeda.

Walaupun disebutkan oleh Baqir S. Manan² bahwa interpretasi terhadap kaidah-kaidah hukum dapat dilakukan oleh kekuasaan kehakiman, legislatif dan eksekutif. Hal ini untuk menghindari kerancuan interpretasi akibat perbedaan pemikiran dan kemampuan masing-masing penegak hukum. Namun kondisi dimana tidak adanya pedoman hukum yang baku dan komprehensif bagi para praktisi hukum (baik formal maupun non-formal) selain kedua undang-undang diatas, dengan sendirinya akan melahirkan berbagai penafsiran dan pemahaman yang berbeda bahkan kontroversial.

Upaya pembaruan dalam bentuk kodifikasi dan unifikasi hukum itu, khususya hukum keperdataan seperti waris, munakahat, dan lain sebagainya muncul ketika lahirnya Kompilasi Hukum Islam di Indonesia. Hukum-hukum tersebut telah mengalami perubahan baik status hukum ataupun dalam prakteknya.

KHI yang tertuang dalam Instruksi Presiden Nomor 1 tahun 1991, dan dilaksanakan dengan Keputusan Menteri Agama Nomor 154 tahun 1991. Menurut para pakar hukum Islam seperti Rachmat Djatnika, Abdul Gani Abdullah, Bustanul Arifin, dan lain sebagainya, KHI merupakan hukum positif Islam untuk melaksanakan peraturan perundangundangan yang berlaku. Ia memiliki konsistensi dengan peraturan perundang-undangan yang kedudukannya lebih tinggi dan dijadikan sebagai rujukan bagi para penegak hukum. ${ }^{3}$

Perubahan hukum baik pelaksanaan hukum Islam pra KHI dan sesudah KHI. Selanjutnya, bila dicermati tentang proses perubahan hukum yang termaktub dalam KHI, ia tidak terlepaskan dari karakteristik perubahan itu sendiri. Dalam hal ini,

2 Bagir Manan, 1995, Pertumbuhan dan Perkembangan Konstitusi Suatu Negara, Mandar Maju Bandung, hlm. 10.

3 Cik Hasan Bisri, 1996, Dimensi-dimensi Kompilasi Hukum Islam, Ulul Albab Press, Bandung, hlm. 13. perubahan hukum meliputi sistematika hukum, materi hukum dan metode hukum.

Pada tataran sistematika hukum, perubahan hukum, menurut pandangan Fazlur Rahman, ${ }^{4}$ memiliki tiga lapis pendekatan:

1. Pendekatan historis yang sederhana dan jujur dalam menemukan makna teks al-Qur'an. Pertama-tama, al-Qur'an harus ditelaah dalam susunan yang kronologis dengan pengujian terhadap wahyu-wahyu paling awal, kemudian;

2. Membedakan antara diktum hukum al-Qur'an, sasaran dan tujuan hukum hukum itu

3. Sasaran al-Qur'an harus dipahami, diramu, dan memperhatikan setting sosiologis dimana Nabi bergerak dan bekerja.

Berbeda pandangan dengan Rahman, AnNaim, ${ }^{5}$ menjelaskan bahwa pola perubahan bisa dimulai dengan pendekatan deduktif dan induktif dari masalah agama dan moral ke masalah politik dan hukum, melainkan pula perubahan dalam makna dan implikasi al-Qur'an dan al-Sunnah.

$\mathrm{KHI}$, bila dipandang dari segi sistematika hukum, ia termasuk kedalam dua kategori perubahan sebagaimana dijelaskan di atas. Hal itu tampak bahwa sistimatika KHI saat ini bersumber pada al-Qur'an dan al-Hadits, dan fatwa-fatwa ulama dengan pelebaran wawasan materinya.

Selanjutnya, Juhaya S. Praja menuturkaaan pada wilayah hukum terbagi kepada dua; wilayah insaniyah dan wilayah uluhiyah. Wilayah insaniyah tertumpu pada aspek-aspek kemanusiaan seperti: sikap, sifat, dan prilaku manusia. Misalnya; Hakim tidak boleh memutuskan perkara ketika sedang marah. Kata marah, dapat diinterpretasikan dengan berbagai argumentasi sepanjang aspekaspek kemanusiaannya ada. Sedangkan wilayah uluhiyah adalah berupa doktrin atau dogma yang termaktub dalam al-Qur'an. Dengan penjelasan tersebut, KHI, bila disorot dengan kajian wilayah, ia termasuk pada wiayah insaniyah karena berupa pemikiran-pemikiran manusia yang terhimpun,

4 Fazlur Rahman, 1994, Islam (Terj.), Salman ITB, Bandung, hlm. 67.

5 Abdullah An-Naim, 1994, Toward an Islamic Reformation Cil Liberties, Human Rights and International Law (diterjemahkan oleh Ahmad Suaedy dan Amiruddin Arrani), Dekonstruksi Syari'ah, LkiS, Yogyakarta, hlm. 28. 
kemudian dilegalisasi menjadi peraturan. Bahkan menurut A. Djazuli, KHI ini dibuat oleh dua kekuatan besar masyarakat Indonesia. Masyarakat ulama dan masyarakat umara. Dari dua kekuatan inilah akhirnya berhasil memunculkan suatu produk hukum yang termuat dalam KHI sebagai pegangan para hakim di lingkungan Peradilan Agama sekaligus bagi masyarakat yang membutuhkannya. ${ }^{6}$

Perubahan dalam kajian materi yang ada di KHI dalam penelitian ini adalah bidang kewarisan (Buku II). Pada dasarnya materi kewarisan ini merupakan suatu peralihan bahkan pembaruan bentuk hukum kewarisan Islam yang sangat dikenal dikalangan fuqaha. Bentuk-bentuk perubahan kewarisan dalam Kompilasi Hukum Islam antara lain:

1. Pasal 171 sub e tentang harta bersama. Di dalam pasal tersebut terungkap bahwa harta bersama itu terpisah dari harta pribadi masingmasing. Bahkan dalam perkawinan poliginiperkawinan serial, wujud harta bersama itu terpisah antara suami dengan masing-masing isteri. Sementara dalam al-Qur'an dan AlHadits, masalah ini tidak dijumpai nashnya secara pasti.

2. Pasal 177 tentang bagian ayah. Dalam pasal ini dirumuskan bahwa ayah mendapat $1 / 3$ bagian dari apabila pewaris tidak meninggalkan anak. Tetapi apabila ada anak, maka ayah mendapat $1 / 6$ bagian. Ketentuan pasal ini tidak terdapat dalam al-Qur'an (surat an-Nisa: 11) dan ijma ulama yang menentukan bagian ayah dengan cara 'ashobah apabila yang meninggal dunia tidak meninggalkan anak. Pasal 183-184 tentang perdamaian dalam pembagian warisan dan pengangkatan wali.

3. Pasal 183 membuka peluang adanya pembagian warisan dalam porsi yang sama (1:1) antara anak laki-laki dan anak perempuan yang menyimpang dari pasal 176 yang mengatur ketentuan anak laki-laki dan anak perempuan.

6 A. Djazuli, Beberapa Aspek Pengembangan Hukum Islam di Indonesia, dalam Eddi Rudiana Arief, et. Al. (ED). 1991, Hukum Islam di Indonesia Pemikiran dan Praktek, Rosdakarya, Bandung, hlm. 235-236.
4. Pasal 189 tentang pemeliharaan keutuhan dan kesatuan lahan yang luasnya kurang dari 2 (dua) hektar, supaya dipertahankan kesatuannya sebagaimana semula.

Sedangkan bagi ahli waris yang membutuhkan uang atau modal, maka bisa dilakukan dengan cara mengganti harta bagian dari harta waris yang didapatnya. Pola pembagian ini sebenarnya bertentangan dengan asas ijbari. Menurut Amir Syarifudin mengungkapkan asas ijbari itu mengandung arti bahwa perpindahan hak milik dari seorang muwarits kepada orang lain (ahli waris) berlaku dengan sendiri menurut ketentuan Allah tanpa tergantung pada kehendak muwarits atau ahli waris.

Berdasarkan uraian di atas, tampaknya pembaruan materi hukum kewarisan yang terdapat dalam Kompilasi Hukum Islam di satu sisi memberikan nilai maslahat, namun disisi lain, bisa dikhawatirkan memiliki interpretasi "menyimpang" dari ketentuan sebagaimana yang termaktub dalam al-Qur'an dan al-Hadits serta ijtihad jumhur ulama.

Pada tataran metode, perubahan hukum, menurut para pakar hukum Islam tidak terlepaskan kepada metode istislah, 'urf, qiyas dan istihsan-dua metode yang terakhir termasuk cara penafsiran hukum berdasarkan penalaran logis atas suatu 'illat hukum, ratio logis. Metode ini, secara faktual epektif, akan tetapi ia juga melahirkan perbedaan sangat besar di kalangan para ahli hukum karena perbedaan pandangan dalam menentukan dan menguji 'illat hukum yang sesungguhnya. Dalam banyak kasus penalaran tersebut (terutama qiyas) melahirkan varian-varian hukum yang idealistik dan tidak sosiologis. ${ }^{7}$

Problem metodologis ini berupaya dipecahkan oleh ahli-ahli hukum lainnya, seperti Al-Ghazali, dengan penawaran metode istislahi yang lebih etis dan pragmatis. Kemudian metode ini dikembangkan oleh al-Syatibi. Melalui karya monumentalnya (al-muwafaqat), ia secara genial berupaya merumuskan sebuah pendekatan

7 Ahmad Hasan, 1994, The early Development of Islamic Yurisprudence (terj.), Kitab Bhavan, New Delhi, hlm. 97. 
metodologis yang didasarkan pada tujuan-tujuan syari'ah (maqashid al-Syari'ah).

Begitu halnya dengan KHI, metode yang dikedepankan adalah metode istislah atau maslahat. Hal itu terbukti dari materi kewarisan terutama pada point angka 4, disampng juga menggunakan metode qiyas dan istihsan.

Berdasarkan permasalahan di atas maka penulis meneliti dalam dengan judul 'Perkembangan Hukum Kewarisan Islam Di Indonesia (Studi Perbandingan Hukum Kewarisan Dalam Kompilasi Hukum Islam Dengan Hukum Kewarisan Dalam Fiqih Konvensional )"

\section{METODE PENELITIAN}

Metode penelitian yang digunakan dalam penelitian ini adalah Terdapat beberapa pendekatan dalam penelitian hukum yaitu pendekatan undang-undang (statute approach), pendekatan kasus (case approach), pendekatan historis (historical approach), pendekatan komparatif (comparative approach), dan pendekatan konseptual (conceptual approach). ${ }^{8}$

\section{HASIL PENELITIAN DAN PEMBAHASAN}

\section{Bentuk-Bentuk Perkembangan Hukum Kewarisan Dalam Kompilasi Hukum Islam (KHI)}

Bentuk-bentuk perkembangaan hukum kewarisan dalam Kompilasi Hukum Islam antara lain:

1. Pasal 171 sub e yang berbunyi "Harta warisan adalah harta bawaan ditambah bagian dari harta bersama setelah digunakan untuk keperlaun pewaris selama sakit sampai meninggalnya, biaya pengurusan jenazah (tajhiz) pembayaran hutang dan pemberian untuk kerabat. " Di dalam pasal tersebut terungkap bahwa harta bersam itu terpisah dari harta pribadi masing-masing. Bahkan dalam perkawinan poligini-perkawinan serial, wujud harta bersama itu terpisah antara suami dengan asing-masing isteri.

Sementara dalam al-Qur' an dan al-Hadits, masalah ini tidak dijumpai nashnya secara

\footnotetext{
8 Ibid. hlm. 93
}

pasti. Ilmu figh cenderung mengabaikan masalah ini sehingga menimbulkan kesan bahwa isteri tidak berperan dalam pembinaan rumah tangga, termasuk aspek financialnya. ${ }^{9}$

Sebagai logika bagi system Harta Bersama, dalam system perkawinan masyarakat Indonesia terdapat sejumlah ciri-ciri:

a. Perlunya dedikasi secara total dari suami dan isteri;

b. Perlunya partisipasi penuh kedua belah pihak dalam membina rumah tangga

c. Keterbukaan dan saling mempercayai

d. Kerja sama dan saling menolong dalam arti luas

e. Adanya jaminan hukum. ${ }^{10}$

Dedikasi seorang isteri telah berubah di zaman kita hari ini, hal ini merupakan adat/kebiasaan yang sudah mengakar di dalam masyarakat kita. Jadi, dalam membina rumah tangga selain menjalankan ketentuanketentuan hukum yang normatif, kita tidak dapat mengabaikan pula peranan adat/tradisi yang pada akhirnya dapat direalisasikan sebagai hukum. ${ }^{11}$

2. Pasal 176 antara lain menyatakan bahwa bagian waris anak laki-laki adalah dua berbanding satu dengan anak perempuan. Namun pasal 299 (yang merupakan ketentuan penutup) menyatakan bahwa dalam menyelesaikan perkara-perkara yang diajukan kepadanya, hakim wajib memperhatikan dengan sungguh-sungguh nilai-nilai hukum yang hidup dalam masyarakat sehingga putusannya sesuai dengan rasa keadilan. Dan hal itu sudah sering dilakukan oleh pengadilan Indonesia, dengan tidak melaksanakan pembagian warisan berdasarkan prinsip anak

9 Amrullah Ahmad, SF.Dkk, 1996, Dimensi Hukum Islam dalam Sistem Hukum Nasional, Gema Insani Press, Jakarta. hlm..59

10 Aulawy, loc.cit, hlm. 60

11 Hasil ijtihad figh---sebagai produk hukum yang diambil dengan menggunakan metode 'urf yang tentu bertujuan mashlahat. Aulawy, Ibid, hlm. 60 . 
laki-laki mendapat bagian dua sedang perempuan satu. ${ }^{12}$

3. Pasal 177 tentang bagian ayah. Dalam pasal ini dirumuskan bahwa ayah mendapat $1 / 3$ bagian dari apabila pewaris tidak meninggalkan anak. Tetapi apabila ada anak, maka ayah mendapat $1 / 6$ bagian. Ketentuan pasal ini tidak terdapat dalam al-Qur an (surat al-Nisa: 11) dan ijma ulama yang menentukan bagian ayah dengan cara 'ashobah apabila yang meninggal dunia tidak meninggalkan anak.

4. Pasala 184 tentang perdamaian dalam pembagian warisan. Pasal ini membuka peluang adanya pembagian warisan dalam porsi yang sama (1:1) antara anak laki-laki dan anak perempuan yang menyimpang dari pasal 176 yang mengatur ketentuan anak laki-laki dan anak perempuan.

5. Pasal 184 tentang pengangkatan wali.

6. Pasal 185 tentang ahli waris pengganti. Apabila istilah "Ahli Waris Pengganti" ini dimaksudkan mengangkat seorang bukan ahli waris menjadi ahli waris, maka jelas hal itu bertentangan dengan hukum kewarisan Islam yang berasaskan ijbari. ${ }^{13}$

7. Pasal 189 tentang pemeliharaan keutuhan dan kesatuan lahan pertanian yang luasnya kurang dari 2 (dua) hektar, supaya dipertahankan kesatuannya sebagaimana semula.

Sedangkan bagi ahli waris yang membutuhkan uang/modal, maka bias dilakukandengan cara mengganti harga bagian dari harta waris yang didapatnya. Pola pembagian ini sebenarnya bertentangan pula dengan asas ijbari. Amir syarifudin mengungkapkan asas ijbari itu mengandung arti bahwa perpindahan hak milik dari seorang muwarits kepada orang lain (ahli waris) berlaku dengan sendiri menurut ketentuan Allah tanpa tergantung pada kehendak muwarits atau ahli waris.

8. Pasal 209 menyatakan bahwa ayah angkat berhak ikut menerima warisan harta

12 Munawir Sadzali, Relevansi Hukum Keluarga Islam dengan Kebutuhan Masa Kini, dalam Amrullah Ahmad, op.cit. hlm. 224.

${ }^{13}$ Lihat Aulawy, Ibid, hlm. 63. peninggalan anak angkatnya. Demikian juga sebaliknya, anak angkat berhak ikut menerima warisan harta peninggalan ayah angkatnya. Kalau mereka tidak menerima wasiat, diberi wasiat wajibah sebanyak-banyaknya $1 / 3$ dari harta warisan anak/orang tua angkatnya. Padahal, dalam hukum Islam, tidak ada anak dan orang tua angkat menerima warisan.

9. Hukum kewarisan Islam di Indonesia mengakui lembaga Gono-Gini, sedangkan dalam hukum Islam tidak ada. ${ }^{14}$

\section{ANALISIS PERKEMBANGAN HUKUM KEWARISAN DALAM KOMPILASI HUKUM ISLAM}

Dari perkembangan hukum kewarisan tersebut di atas dapat di analisa lebih dalam perbandingan hukum kewarisan dalam kompilasi hukum islam dengan hukum kewarisan dalam fiqih konvensional sebagai berikut :

Hukum kewarisan yang termuat dalam KHI terdiri atas VI bab dan 44 pasal (pasal 171-214), dari segi yuridis formalnya, perkara kewarisan belum pernah dibahas dalam peraturan perundang-undangan di Indonesia, baru dalam KHI aturan tersebut diberlakukan, selama ini para hakim peradilan agama menetapkan hukum kewarisan berdasarkan sumber hukum, yaitu Alquran dan hadis, dan kitab-kitab fikih.

KHI membawa perubahan yang cukup penting tentang sistem kewarisan yang selama ini dianut oleh masyarakat beragama Islam di Indonesia pada umumnya menggunakan kitab-kitab yang bersumber dari mazhab sunni yang menganut sistem kewarisan patrilinier. ${ }^{15}$ Sedang sistem kewarisan yang dianut KHI adalah sebagaimana tercantum dalam Q.S. an-Nisa (4): 7 dan 11, yaitu sistem kewarisan bilateral. Menurut sistem ini, anak laki-laki atau cucu dari anak perempuan

14 Munawir Sadzali, op.cit, hlm. 225.

15 Sistem kewarisan patrilinier adalah sistem kewarisan yang mengikuti (dipengaruhi) sistem kekeluargaan adat Arab pra Islam yang disesuaikan dengan ketentuan-ketentuan kewarisan syar'i. Lihat Imron AM, Hukum Kewarisan dan Hibah dalam Kompilasi Hukum Islam, Mimbar Hukum, No. 24, Tahun 1996, hlm. 45 
(zawi al arham) adalah sama-sama sebagai ahli waris asabah zawi al furud, maka tidak berhak mewarisi. Dalam KHI, apabila semua ahli waris ada, maka yang berhak mendapat warisan hanya anak, ayah, ibu, janda atau duda. Dalam pasal ini kata anak disebut secara mutlak tanpa keterangan laki-laki/perempuan. Ini berarti kalau ada anak, tanpa dibedakan apakah anak laki-laki atau anak perempuan, maka menghijab terhadap saudarasaudara kandung atau paman pewaris. Sedangkan menurut fikih konfensional, kalau anak tersebut perempuan maka hanya dapat menghijab nuqșan atau mengurangi bagian ahli waris asobah. ${ }^{16}$

Seorang terhalang menjadi ahli waris apabila dengan putusan hakim yang telah mempunyai kekuatan hukum yang tetap, dihukum karena: (a) dipersalahkan telah membunuh atau mencoba membunuh atau menganiaya berat para pewaris; (b) dipersalahkan secara memfitnah telah mengajukan pengaduan bahwa pewaris telah melakukan suatu kejahatan yang diancam dengan hukuman 5 tahun penjara atau hukuman yang lebih berat. Pembaruan dalam pasal ini memberikan tambahan ketentuan hal-hal yang dapat menghalangi hak seseorang untuk mewarisi. Dalam Kompilasi Hukum Islam disebutkan di atas bahwa di samping faktor membunuh, faktor percobaan pembunuhan dan menganiaya berat juga menjadi penyebab terhalangnya hak seseorang untuk dapat mewarisi (Pasal $173 \mathrm{KHI}$ ).

Dalam kitab-kitab fikih, ulama bersepakat bahwa hal-hal yang dapat menghalangi hak mewarisi ada tiga, yaitu karena menjadi hamba sahaya, berbeda agama dan membunuh pewaris. Faktor membunuh menjadi penghalang mewarisi jika memang benar-benar telah melakukan pembunuhan terhadap pewaris. Ulama fikih tidak menetapkan apakah orang yang melakukan percobaan pembunuhan dan penganiayaan berat terhadap pewaris juga menghalangi hak kewarisan seseorang. ${ }^{17}$ Ketentuan melakukan percobaan pembunuhan dan menganiaya berat sebagai

16 Alimuddin, 2011, Kompilasi Hukum Islam Sebagai Hukum Terapan Bagi Hakim Pengadilan Agama, Alauddin University Press, Makassar, hlm. 75.

17 Abdul hamid, Muhammad Muhyiddin, Ahkm alMawarith fi Shara'at al-Islamiyah ala Mazahib alArba'ah, t.tp: Dar al-Kitab al-Arabi, t.t, hlm. 37-49. penghalang hak mewarisi merupakan hasil ijtihad para ahli hukum Islam Indonesia.

Pembaruan hukum kewarisan berikutnya dapat diperhatikan dalam ketentuan Pasal 185 ayat (1) KHI yang menyatkan bahwa ahli waris yang meninggal lebih dahulu daripada pewaris, kedudukannya dapat digantikan oleh anaknya. Bagian untuk ahli waris penggantinya tidak boleh melebihi bagian ahli waris yang sederajat dengan yang digantikannya (Pasal 185 ayat (2) KHI). Ketentuan dalam pasal ini sering disebut dengan ketentuan mengenai ahli waris pengganti (mawall) ${ }^{18}$

Ketentuan mengenai ahli waris pengganti ini tidak ditemukan dalam kitab-kitab fikih. Pada umumnya, ulama fikih menetapkan kedudukan seseorang sebagai ahli waris tidak dapat digantikan oleh anaknya jika ia lebih dahulu meninggal daripada pewaris, sehingga dalam kita fikih tidak dikenal adanya ahli waris pengganti.

Pembaruan selanjutnya terjadi dalam ketentuan mengenai syarat seseorang yang hendak mewasiatkan hartanya harus memenuhi umur sekurang-kurangnya 21 tahun (Pasal 194 ayat (1) KHI). Ketentuan ini berkaitan erat dengan batasan seseorang yang dapat dianggap dewasa. Jika seseorang belum mencapai batasan umur ini maka masih belum dianggap dewasa dan belum patut melakukan perbuatan hukum seperti mewasiatkan hartanya. Ketentuan batas usia minimal ini tidak ditemukan dalam kitab-kitab fikih. Ulama fikih dari mazhab Hanafi dan mazhab Syafi'i hanya mensyaratkan bahwa pewasiat harus sudah baligh (dewasa), sedangkan ulama dari mazhab Maliki dan Hanbali hanya mensyaratkan bahwa pewasiat harus sudah mumayyiz (cukup

18 Ketentuan dalam pasal ini, dalam sejarah perkembangan pemkiran hukum Islam di Indonesia pada tahun 1964-an pernah menjadi obyek perdebatan yang serius antara Prof. Dr. Hazairin, S.HLM., Prof. Dr. HLM. Mahmud Yunus dan Prof. HLM. Thaha Umar Yahya, MA. Prinsip ahli waris pengganti ini merupakan pendapat dari Prof. Dr. Hazairin, S.HLM. pendapatnya ini mendapat penentangan yang keras dari Prof. Dr. HLM. Mahmud Yunus dan Prof. HLM. Thaha Umar Yahya, MA, Majalah Ilmiah Islamiyah, 1964. 
dewasa).${ }^{19}$ Pada umumya para ulama menyatakan bahwa usia baligh telah dipenuhi jika seseorang telah berumur lima belas tahun dan atau sudah keluar sperma bagi laki-laki dan telah berusia 9 tahun atau sudah menstruasi bagi wanita. Sedangkan usiamumayyiz itu di bawah usia baligh.

Pembaruan berikutnya terjadi dalam ketentuan Pasal 195 ayat (2) KHI yang menyatakan bahwa wasiat harus dilakukan di hadapan dua orang saksi atau notaris baik secara lisan atau tertulis. Ketentuan ini pun tidak dijumpai dalam kitab-kitab fikih. Ulama fiqh tidak memasukkan ketentuan adanya dua orang saksi bagi sahnya wasiat. Mereka menetapkan bahwa wasiat mempunyai empat rukun, yaitu pewasiat penerima wasiat, benda yang diwasiatkan dan sighat dan qabul. ${ }^{20}$ Ulama fikih tidak memasukkan dua orang saksi, apalagi notaris ke dalam rukun wasiat

Kondisi sekarang berbeda dengan kondisi pada saat kitab-kitab fikih klasik itu ditulis. Pada saat itu, kemaslahatan hukum dalam wasiat sudah dapat diperoleh meskipun tanpa harus menetapkan ketentuan dua orang saksi atau pejabat hukum seperti notaris sebagai rukun wasiat. Pada masa itu orang masih menjunjung tinggi nilai-nilai tradisi seperti tradisi menyampaikan wasiat pada penerimanya. Kondisi sekarang sudah berubah, kebanyakan orang sekarang kurang dapat dipercaya ketika misalnya mengaku menerimawasiat dari seseorang. Pengakuannya ini harus dibuktikan dengan kesaksian dua orang saksi atau dengan akta notaris. Dengan demikian ketentuan ini bisa diterima dengan alasan-alasan tersebut.

Pembaruan berikutnya terjadi dalam ketentuan Pasal 197 ayat (1) KHI yang menyatakan bahwa penerima wasiat terhalang jika; pertama, membunuh, mencoba membunuh atau menganiaya berat terhadap pewasiat; kedua, menfitnah pewasiat bahwa pewasiat telah melakukan kejahatan dengan hukuman lima tahun

19 Al-Ẓahir, Ibnu Hazm,tt, al-Muhalla, Dar al-Fikr, Beirut, hlm. 278-286.

20 Abual-'Ain Badran,tt, Ahkam al-Wașayawa al-Hibah Mu'assasah Shabbab al-Jamiah, Iskandariyah hlm. 130. atau lebih; ketiga, dengan kekerasan dan ancaman, mencegah pewasiat untuk membuat atau mencabut atau merubah wasiat untuk kepentingan penerima wasiat.

Ulama fikih bersepakat bahwa penerima wasiat terhalang hak terima wasiatnya jika ternyata membunuh pewasiat baik dilakukan sendiri, bersama orang lain atau melalui perantara orang lain. Sedangkan dalam kitab-kitab fikih, yang menjadi penghalang adalah melakukan pembunuhan terhadap pewasiat.

Pada dasarnya ketentuan membunuh merupakan ketentuan maksimal yang ditetapkan syari'ah. Oleh karena itu, manusia Edi Gunawan, Pembaruan Hukum Islam tidak berhak mengurangi ketentuan maksimal ini. Dengan demikian, hanya faktor membunuhlah yang dapat menyebabkan terhalangnya hak menerima wasiat. Kejahatankejahatan lain seperti melakukan percobaan pembunuhan dan penganiayaan berat, seperti dalam pasal ini, dapat saja ditetapkan sebagai faktor yang dapat menjadi penghalang menerima wasiat jika kejahatan-kejahan itu dimaksudkan untuk membunuh pewasiat. Akan tetapi jika tidak demikian, maka tidak dapat menjadi faktor penghalang.

Pembaruan ini juga dapat diperhatikan pada ketentuan Pasal 207 KHI yang menyatakan bahwa wasiat tidak diperbolehkan kepada orang yang melakukan pelayanan perawatan dan orang yang memberikan tuntunan kerohanian kepada pewasiat hingga ia meninggal, kecuali jika ditentukan dengan tegas dan jelas untuk membalas jasanya, dan juga dalam ketentuan dalam Pasal 208 KHI yang menyatakan bahwa wasiat tidak berlaku bagi notaris dan saksi-saksi pembuat akta tersebut.

Ketentuan semacam itu tidak dijumpai dalam kitab-kitab fikih. Ulama fikih pada umumnya menetapkan syarat-syarat bagi calon penerima wasiat. Syarat-syarat itu meliputi, penerima wasiat masih hidup pada saat wasiat dibuat, penerima wasiat harus jelas identitasnya, penerima wasiat harus berupa orang yang dapat diakui hak dan kepemilikannya dan penerima wasiat tidak membunuh pewasiat.

Ketentuan tidak diperbolehkan kepada orang yang melakukan pelayanan perawatan dan orang yang memberikan tuntunan kerohanian kepada 
pewasiat hingga ia meninggal kecuali jika ditentukan dengan tegas dan jelas untuk membalas jasanya, dan ketentuan wasiat tidak berlaku bagi notaris dan saksi-saksi pembuat akta tersebut seperti dalam Pasal 107 dan 108 KHI, belum pernah ditemukan dalam kitab-kitab fikih. Ketentuan ini merupakan ketentuan baru yang merupakan hasil ijtihad para perumus KHI. Ketentuan-ketentuan ini merupakan upaya untuk menutup jalan ke arah terjadinya keburukan (mafsadat). Upaya ini dalam kaidah fikih disebut sebagai prinsip sadd al-zari'at.

Pembaruan ini juga dapat diperhatikan pada 209 ayat (1) dan (2) KHI yang menyatakan bahwa orang tua angkat yang tidak mendapat wasiat diberi wasiat wājibah sebanyak-banyaknya $1 / 3$ dari harta warisan anak angkatnya. Ada juga anak angkat yang tidak mendapat wasiat diberi wasiat wājibah sebanyak-banyaknya $1 / 3$ dari warisan orang tua angkatnya. Ketentuan memberi wasiat wajibah kepada orang tua angkat dan anak angkat tidak ditemukan dalam kitab-kitab fikih empat mazhab dan bahkan dari mazhab Zahir sekali pun. Istilah wasiat wājibah sendiri tidak dikenal dalam kitab-kitab fikih empat mazhab.

Anak angkat, KHI tidak menjelaskan dengan tegas, bahwa menurut hukum Islam anak angkat tidak mendapat kewarisan dari orang tua angkatnya, bagitu juga sebaliknya, tetapi bisa mendapatkan kewarisan dengan jalur lain. Namun, di sisi lain anak angkat adalah sosok yang mempunyai pertalian hubungan kemanusiaan yang bersifat khusus dalam hal kedekatan dan saling membantu serta penempatan statusnya dalam keluarga oleh orang tua angkatnya sebagai layaknya keluarga sendiri (anak sendiri). ${ }^{21}$ Oleh karena itu, wajarlah ketika KHI mengakomodir memberikan kepada anak angkat yang orang tua angkatnya meninggal lebih dahulu atau sebaliknya, yang tidak menerima wasiat, maka diberikan harta warisan (tirkah) melalui wasiat wājibah dengan memberikan batasan tidak melibihi sepertiga dari harta warisan orang tua angkatnya atau anak angkatnya.

Namun ada juga yang berpendapat bahwa anak angkat dan orang tua angkat $d$ tetap tidak

\footnotetext{
21 Alimuddin, loc.cit. hlm. 78.
}

bisa mengakibatkan adanya hubungan saling mewarisi, meskipun dengan cara wasiat wajibah. Orang tua angkat dan anak angkat mungkin saja mendapat bagian dari harta warisan dengan cara hibah. Cara inilah yang mungkin dapat diterima karena hibah itu bisa kepada siapa saja termasuk kepada orang tua angkat dan anak angkat.

Dari perbandingan hukum kewarisan di KHI dan fikqih konvensional tersebut di atas di karenakan :

1. Indonesia sebagai negara berkembang yang sedang membangun menghendaki keseragaman (unifikasl) hukum dalam bentuk kodipikasi (Hukum Tertulis) sebagai implikasi dari eksistensi lembaga peradilan.

2. Berubahnya zaman serta kebutuhan masyarakat indonesia terhadap kepastian hukum yang akan di anutnya. Taghayurul ahkam bitaghayuril azminah wal amkinah wal awal'id. Penegasan kaidah fikih sebagai dasar akan butuhnya perubahan hukum yang bersekala lokal ke- Indonesiaan.

3. Agar hukum kewarisan dalam KHI dapat dijadikan hukum terapan (materii) bagi instansi Perintah (Pengdilan Agama) dan masyarakat Indonesia dalam menyelesaikan perkaraperkara kewarisan.

\section{PENUTUP}

Berdasarkan uraian dan penjelasan yang dikemukakan sebelumnya, akhirnya dapat disimpulkan dan kami sarankan sebagai berikut:

\section{Simpulan}

a. Bentuk-bentuk perkembangan hukum kewarisan dalam KHI banyak memasukkan unsur-unsur hukum adat dan kepentingankepentingan yang dibutuhkan masyarakat Indonesia masa sekarang. Maka banyak bentuk-bentuk hukum kewarisan yang belum tertuang dalam fiqh konvensional (figh almawarits), namun hal itu telah termuat dan terkodifikasikan dalam hukum kewarisan $\mathrm{KHI}$, Antara lain: pasal 171 tentang Harta Bersama, pasal 177 tentang pembagian ayah secara 'ashabah. Pasal 209 yang menyatakan bahwa ayah angkat dan anak angkat menerima warisan, dan bila mereka tidak menerima 
wasiat, maka berhak menerima wasiat wajibah. Dan KHI pun mengakui lembaga gono-gini padahal fiqh klasik tidak mengakuinya (tidak menjadikan sub bahasannya).

Disamping itu, adapula pertentanganpertentangan kebijakan hukum kewarisan yang telah termuat dalam KHI antara pasal yang satu dengan pasal-pasal yang lainnya, antara lain: pasal 176 tentang pembagian anak laki-laki dengan anak perempuan. Hal ini bertentangan dengan pasal 229 (yang merupakan ketentuan penutup), yang menyatakan bahwa dalam menyelesaikan perkara-perkara, hakim wajib memperhatikan nilai-nilai hukum yang hidup dalam masyarakat sehingga putusannya sesuai dengan rasa keadailan. Dalam hal ini, Pengadilan Indonesia, sering melakukan pembagian warisan tidak berdasarkan prinsip 2 banding 1 bagi anak laki-laki dan perempuan. Juga, pasal 183 tentang perdamaian dalam pembagian warisan yang dapat bertentangan pula dengan pasal 176. Demikian juga, pasal 185 tentang ahli waris pengganti dan pasal 189 tentang keutuhan dan kesatuan lahan pertanian yang luasnya kurang dari 2 (dua) hektar, bertentangan dengan asas ijbari dalam hukum kewarisan Islam (fiqh konvensional).

b. Perbandingan Hukum Kewarisan Dalam Kompilasi Hukum Islam Dengan Hukum Kewarisan Dalam Fiqih Konvensional

Dari perkembangan Kompilasi Hukum Islam serta Perbandingan hukum kewarisan dalam Kompilasi Hukum Islam dengan hukum kewarisan dalam fiqih konvensional tersebut di atas dapat di simpulkan di karenakan :

a. Indonesia sebagai negara berkembang yang sedang membangun menghendaki keseragaman (unifikasi) hukum dalam bentuk kodipikasi (Hukum Tertulis) sebagai implikasi dari eksistensi lembaga peradilan.

b. Berubahnya zaman serta kebutuhan masyarakat indonesia terhadap kepastian hukum yang akan di anutnya. Taghayurul ahkam bitaghayuril azminah wal amkinah wal awal'id. Penegasan kaidah fikih sebagai dasar akan butuhnya perubahan hukum yang bersekala lokal ke- Indonesiaan. c. Agar hukum kewarisan dalam KHI dapat dijadikan hukum terapan (materii) bagi instansi Perintah (Pengdilan Agama) dan masyarakat Indonesia dalam menyelesaikan perkara-perkara kewarisan.

\section{Saran}

Dari kesimpulan yang ada dan dari hasil penelitian yang telah dilakukan, dapat dikemukakan beberapa saran yang diharapkan dapat menjadi bahan pemikiran guna memberikan solusi bagi permasalahan yang dihadapi, yaitu :

1. Dalam perubahan dari fiqih konvensional ke KHI harus tetap mengunakan kaidah kaidah fiqih yang tidak bertentangan dan sesuai dengan keadaan bangsa Indonesia.

2. Berubahnya zaman serta kebutuhan masyarakat Indonesia terhadap kepastian hukum yang akan di anutnya, sehingga diharapkan mujtahid mujtahid untuk selalu melakukan pembaharuan hukum

3. Semua pembaharuan hukum di KHI dapat dijadikan hukum terapan (materii) bagi instansi Perintah (Pengadilan Agama) dan masyarakat Indonesia dalam menyelesaikan perkaraperkara kewarisan.

\section{DAFTAR PUSTAKA}

Abdullah An-Naim, 1994, Toward an Islamic Reformation Cil Liberties, Human Rights and International Law (diterjemahkan oleh Ahmad Suaedy dan Amiruddin Arrani), Dekonstruksi Syariah, LkiS, Yogyakarta.

Abdul Gani Abdullah, 1992, Pengantar Kompilasi Hukum Islam dalam Tata Hukum Indonesia, Gema Insani Press, Jakarta.

Abdul hamid, Muhammad Muhyiddin, Ahkm alMawarith fi Shara'at al-Islamiyah ala Mazahib alArba'ah, t.tp: Dar al-Kitab al-Arabi

Abual-'Ain Badran,tt, Ahkam al-Wașayawa al-Hibah Mu'assasah Shabbab al-Jamiah, Iskandariyah

Ahmad Hasan, 1994, The early Development of Islamic Yurisprudence (terj.), Kitab Bhavan, New Delhi. 
Alimuddin, 2011, Kompilasi Hukum Islam Sebagai Hukum Terapan Bagi Hakim Pengadilan Agama, Alauddin University Press, Makassar

Al-Ẓahir, Ibnu Hazm, tt, al-Muhalla, Dar al-Fikr, Beirut

Amrullah Ahmad, SF.Dkk, 1996, Dimensi Hukum Islam dalam Sistem Hukum Nasional, Gema Insani Press, Jakarta.

Bagir Manan, 1995, Pertumbuhan dan Perkembangan Konstitusi Suatu Negara, Mandar Maju Bandung.
Cik Hasan Bisri, 1997, Peradilan Islam dalam Tatanan Masyarakat Indonesia, Ulil Albab Press, Bandung.

Eddi Rudiana Arief, et. Al. (ED). 1991, Hukum Islam di Indonesia Pemikiran dan Praktek, Rosdakarya, Bandung.

Fazlur Rahman, 1994, Islam (Terj.), Salman ITB, Bandung.

Imron AM, Hukum Kewarisan dan Hibah dalam Kompilasi Hukum Islam, Mimbar Hukum, No. 24, Tahun 1996 